\title{
PENGARUH MODEL PEMBELAJARAN DAN MOTIVASI BELAJAR TERHADAP PEMAHAMAN KONSEP MATEMATIKA
}

\begin{abstract}
Sodri ${ }^{1}$
ABSTRACT: The purpose of this study to know the influence of learning model on the students' understanding of mathematical concepts, know the influence of learning motivation to the students' understanding of mathematical concepts. Furthermore, to konow the influence of learning models and learning motivation together to the students' understanding the concept of mathematics. The research method used is experiment. The sample size is 60 students consisting of 30 students of experimental class and 30 students of control class, with sampling technique used is cluster sampling. The data were collected with the technique of giving test to understanding the concept of mathematics and with the dissemination of motivation questionnaire. Data analysis consisted of testing the research instrument with validity, reliability, difficulty index, and distinguishing power. Furthermore, the test requirements analysis with normality test and homogeneity test. Hypothesis testing with 2 way ANOVA test and Tukey test. The research results showed: 1) There is a significant influence of learning model on the understanding of mathematics concepts of publik Senior High School students in Pandeglang District. This is evidenced by Sig $=0.000<0.05$ and Fcount $=98,341,2$ ) There is a significant influence of learning motivation on the understanding of mathematics concepts of publik Senior High School students in Pandeglang District. It is proved by Sig $=0.000<0,05$ and Fcount $=35,896,3$ ) There is significant interactive influence of learning model and learning motivation together on the understanding of mathematics concepts of publik Senior High School students in Pandeglang District. It is proved by Sig =0,016 <0,05 and Fcount $=6,146$. The results of research is useful to improve understanding of mathematics concepts.
\end{abstract}

Keywords: Learning Models, Motivation to Learning, Understanding of Mathematics Concepts

ABSTRAK: Penelitian ini bertujuan untuk mengetahui pengaruh model pembelajaran dan
motivasi terhadap pemahaman konsep matematika siswa. Penelitian ini menggunakan
metode eksperimen yang berdesain factorial design $2 \times 2$. Sampel penelitian ini sebanyak
60 siswa yang terdiri atas 30 siswa kelas eksperimen dan 30 siswa kelas kontrol, yang
diambil menggunakan teknik cluster sampling. Pengumpulan data dilaksanakan dengan
teknik pemberian tes kemampuan pemahaman konsep matematika dan angket motivasi
belajar. Pengujian hipotesis dilakukan dengan uji ANOVA 2 jalur dan uji Tukey.
Berdasarkan hasil penelitian diperoleh kesimpulan bahwa: 1 ) Terdapat pengaruh yang
signifikan model pembelajaran terhadap pemahaman konsep matematika siswa SMA
Negeri di Kabupaten Pandeglang. Hal tersebut dibuktikan dengan Sig $=0,000<0,05$
dan Fhitung $=98,341,2$ ) Terdapat pengaruh yang signifikan motivasi belajar terhadap
pemahaman konsep matematika siswa SMA Negeri di Kabupaten Pandeglang. Hal
tersebut dibuktikan dengan Sig $=0,000<0,05$ dan Fhitung $=35,896,3$ Terdapat
pengaruh interaktif yang signifikan model pembelajaran dan motivasi belajar

${ }^{1}$ Guru Matematika, SMA Negeri 4 Pandeglang, Email: abisodri.putri@gmail.com 
terhadap pemahaman konsep matematika siswa SMA Negeri di Kabupaten Pandeglang. Hal tersebut dibuktikan dengan Sig = 0,016 $<0,05$ dan $F_{\text {hitung }}=6,146$.

Kata Kunci: Model Pembelajaran, Motivasi Belajar, Pemahaman Konsep Matematika

\section{PENDAHULUAN}

Untuk manghadapi tantangan zaman yang dinamis, berkembang dan semakin maju diperlukan sumber daya manusia yang memiliki keterampilan intelektual tingkat tinggi yang melibatkan kemampuan penalaran yang logis, sistematis, kritis, cermat, dan kreatif dalam mengkomunikasikan gagasan atau dalam memecahkan masalah. Kemampuan-kemampuan tersebut pada dasarnya dapat dikembangkan melalui pendidikan, pendidikan merupakan suatu proses membantu manusia dalam mengembangkan dirinya, sehingga mampu menghadapi segala perubahan dan permasalahan dengan sikap terbuka dan kreatif tanpa kehilangan identitas dirinya Perkembangan Ilmu Pengetahuan dan Teknologi (IPTEK) yang begitu pesat menuntut generasi penerus mempersiapkan diri untuk menjadi lebih matang dan lebih baik. Menuntut ilmu merupakan satu-satunya cara agar manusia lebih baik, sehingga dapat mengimbangi setiap perkembangan zaman agar mereka tak tertinggal jauh oleh kemajuan teknologi. Matematika sering disebut sebagai "ratunya ilmu" karena menghubungkan berbagai ilmu lain seperti kimia, fisika, biologi, astronomi, kebumian, geologi, komputer dan bidang-bidang lainnya. Koneksi ini timbul melalui berbagai subdisiplin yang memanfaatkan konsep-konsep dari berbagai disiplin ilmu. Sebagai contoh kecil dalam biologi atau fisika tentang pertumbuhan dan peluruhan melibatkan penerapan konsep-konsep matematika tentang barisan dan deret, baik deret aritmatika maupun deret geometri. Maka tidak berlebihan bila matematika dipandang sebagai salah satu ilmu dasar, baik aspek terapannya maupun aspek penalarannya, karena mempunyai peranan yang penting dalam upaya memahami ilmu dan teknologi (IPTEK). Dengan demikian, matematika perlu dikuasai oleh segenap warga negara Indonesia khusunya pelaku pendidikan baik penerapannya maupun pola pikirnya. Pendidikan matematika merupakan wahana untuk mengembangkan semua potensi yang dimiliki siswa termasuk pemahaman konsep matematika.

Kemampuan pemahaman konsep merupakan salah satu tuntutan kurikulum saat ini yang perlu untuk ditingkatkan. Pemahaman konsep tidak hanya mengenal konsep, tetapi siswa harus dapat menghubungkan antara konsep yang satu dengan konsep yang lain yang masih ada kaitannya. Kemampuan ini sangat berguna dalam menyelesaikan suatu permasalahan matematika baik yang bersifat konsep maupun konteks. Pemahaman konsep merupakan salah satu aspek dari tiga aspek penilaian matematika. Penilaian pada aspek pemahaman konsep ini bertujuan untuk mengetahui sejauh mana siswa mampu menerima dan memahami konsep dasar matematika yang telah diterima siswa. Pemahaman konsep matematika merupakan kompetensi yang ditujukkan siswa dalam memahami konsep matematika, dan melakukan prosedur secara luwes, akurat, efisien, dan tepat. Siswa akan lebih mudah untuk mempelajari sesuatu apabila belajar pada apa yang telah diketahui sebelumnya, karena dalam mempelajari materi matematika yang baru, pengalaman sebelumya akan mempengaruhi kelancaran proses belajar matematika selanjutnya. Suatu konsep bukanlah sesuatu yang dihafal, tetapi untuk dipahami maknanya. 
Beberapa uraian di atas mengindikasikan bahwa kemampuan pemahaman konsep matematika sangat penting untuk ditumbuh kembangkan, karena kemampuan tersebut merupakan kemampuan yang harus dimiliki siswa untuk kebutuhan sekarang dan masa yang akan datang. Kenyataan di lapangan menunjukkan kemampuan pemahaman konsep matematika siswa masih rendah. Rohaeti (2003) menyatakan bahwa rata-rata KKM siswa berada pada posisi kualifikasi kurang dalam mengkomunikasikan gagasan-gagasan matematika termasuk dalam kategori kurang sekali.

Oleh karena itu, perlu mengetahui faktor-faktor yang mempengaruhi keampuan pemahaman konsep matematika pesertda didik, baik faktor internal maupun faktor eksternal. Motivasi adalah salah satu faktor internal siswa yang sangat mempengaruhi pemahaman konsep matematika yang pada akhirnya mempengaruhi hasil belajar siswa, sedangkan model pembelajaran merupakan faktor eksternal yang dapat diupayakan oleh guru sebagai pengajar dan pendidik.

\section{METODE PENELITIAN}

Penelitian ini menggunakan metode eksperimen. Penelitian ini akan menguji pengaruh model pembelajaran dan motivasi belajar terhadap pemahaman konsep matematika. Variabel bebas dalam penelitian ini adalah model pembelajaran $\left(\mathrm{X}_{1}\right)$ dan motivasi belajar $\left(\mathrm{X}_{2}\right)$. Model pembelajaran sebagai variabel perlakuan dan motivasi belajar sebagai variabel atribut, sedangkan variabel terikatnya adalah pemahaman konsep matematika (Y). Adapun desain yang digunakan dalam penelitian ini adalah factorial design $2 \times 2$ seperti pada Tabel 1 berikut.

Tabel 1. Desain Penelitian

\begin{tabular}{cccc}
\hline \multirow{2}{*}{ Motivasi Belajar } & \multicolumn{3}{c}{ Model Pembelajaran } \\
& $\begin{array}{c}\text { PBL } \\
\left(A_{1}\right)\end{array}$ & $\begin{array}{c}\text { Konvensional } \\
\left(A_{2}\right)\end{array}$ & $\sum B$ \\
\hline Tinggi & $A_{1} B_{1}$ & $A_{2} B_{1}$ & $\sum B_{1}$ \\
Rendah & $A_{1} B_{2}$ & $A_{2} B_{2}$ & $\sum B_{2}$ \\
$\sum A$ & $\sum A_{1}$ & $\sum A_{2}$ & \\
\hline
\end{tabular}

Keterangan :

$A_{1} \quad$ : Kelompok siswa yang diberikan model pembelajaran prblem based learning (PBL)

$\mathrm{A}_{2} \quad$ : Kelompok siswa yang diberikan model pembelajaran Konvensional

$\mathrm{B}_{1} \quad$ : Kelompok siswa yang memiliki motivasi belajar tinggi

$B_{2} \quad$ : Kelompok siswa yang memiliki motivasi belajar rendah

$A_{1} B_{1}$ : Siswa yang diberikan model pembelajaran prblem based learning (PBL) dengan memiliki motivasi belajar tinggi

$A_{2} B_{1}$ : Siswa yang diberikan metode pembelajaran konvensional dengan 
memiliki motivasi belajar tinggi

$\mathrm{A}_{1} \mathrm{~B}_{2} \quad$ : Siswa yang diberikan model pembelajaran prblem based learning (PBL) dengan memiliki motivasi belajar rendah

$\mathrm{A}_{2} \mathrm{~B}_{2} \quad$ : Siswa yang diberikan model pembelajaran konvensional dengan memiliki motivasi belajar rendah

Populasi dalam penelitian ini adalah seluruh siswa kelas XII IPA SMA Negeri Pandeglang yang terdaftar pada tahun pelajaran 2017/2018. Cara pengambilan sampel dilakukkan dengan cluster sampling. (Sugiyono, 2004: 94) mengungkapkan bahwa teknik cluster sampling umumnya dilakukan melalui 2 tahap yaitu menentukan orang-orang yang ada pada kelas/daerah itu secara sampling pula. Sejalan dengan pendapat tersebut, penentuan sampel dalam penelitian ini dilakukkan melalui dua tahap, yaitu: pertama, pengambilan kelas untuk kelompok eksperimen dan kontrol dilakukan dengan teknik simple random sampling (sampel acak sederhana). Kedua pengambilan sampel subjek dilakukan dengan teknik sampling sistematis (Sugiyono, 2006: 60) yaitu teknik pengambilan sampel berdasarkan urutan dari anggota populasi yang telah diberi nomor urut. Dalam hal ini sampel individu diambil berdasarkan tes motivasi belajar terhadap matematika, penulis mengambil 15 siswa yang urutan motivasi belajar tinggi dan 15 siswa yang urutan motivasi belajar rendah pada kelas eksperimen serta 15 siswa yang urutan motivasi belajar tinggi dan 15 siswa yang urutan motivasi belajar rendah pada kelas kontrol.

\section{HASIL DAN PEMBAHASAN}

Tahap penelitiannya yaitu tahap analisis pendahuluan meliputi statistik deskriptif dengan mendeskripsikan data masing-masing variabel. Selanjutnya dilakukan uji persyaratan analisis data yaitu uji normalitas dan homogenitas data. Jika data dinyatakan layak maka dilanjutkan dengan pengujian hipotesis penelitian menggunakan ANOVA 2 Jalur. Berikut disajikan rangkuman data hasil penelitian seperti pada Tebel 2 berikut.

Tabel 2. Rangkuman Data Deskriptif

\begin{tabular}{cccc}
\hline & \multicolumn{3}{c}{ Model Pembelajaran Kooperatif } \\
Minat Belajar & Tipe PBL & Total \\
& $\left(A_{1}\right)$ & $\begin{array}{c}\text { Konvensional } \\
\left(A_{2}\right)\end{array}$ & \\
\hline Motovasi Belajar Tinggi & $n=15$ & $n=15$ & $n=30$ \\
$\left(B_{1}\right)$ & $\bar{X}=86,93$ & $\bar{X}=70,93$ & $\bar{X}=78,93$ \\
& & & \\
Motovasi Belajar Rendah & $n=4,652$ & $s=4,399$ & $s=9,273$ \\
$\left(B_{2}\right)$ & $\bar{X}=15$ & $n=15$ & $n=30$ \\
& $s=5,856$ & $\bar{X}=66,4$ & $\bar{X}=71,2$ \\
Total & $n=30$ & $n=30$ & $s=7,232$ \\
& $\bar{X}=81,47$ & $\bar{X}=68,67$ & $\bar{X}=73,71$ \\
\hline
\end{tabular}




\section{Keterangan :}

$A_{1} \quad$ : Kelompok siswa yang diberikan model pembelajaran problem based learning (PBL)

$\mathrm{A}_{2} \quad$ : Kelompok siswa yang diberikan model pembelajaran konvensional

$\mathrm{B}_{1} \quad$ : Kelompok siswa yang memiliki motivasi belajar tinggi

$\mathrm{B}_{2} \quad$ : Kelompok siswa yang memiliki motivasi belajar rendah

$A_{1} B_{1}$ : Kelompok siswa yang diberikan model pembelajaran problem based learning ( $\mathrm{PBL}$ ) dengan memiliki motivasi belajar tinggi

$A_{2} B_{1}$ : Kelompok siswa yang diberikan metode pembelajaran konvensional dengan memiliki motivasi belajar tinggi

$A_{1} B_{2}$ : Kelompok siswa yang diberikan model pembelajaran problem based learning ( $\mathrm{PBL}$ ) dengan memiliki motivasi belajar rendah

$\mathrm{A}_{2} \mathrm{~B}_{2}$ : Kelompok siswa yang diberikan model pembelajaran konvensional dengan memiliki motivasi belajar rendah

Pengukuran data pemahaman konsep matematika menggunakan instrumen tes obyektif berbentuk pilihan ganda dengan 25 buah butir soal. Masing-masing butir diberi skor 1 jika jawaban benar dan 0 jika jawaban salah, sehingga rentang perolehan skor responden adalah 0 sampai dengan 25. Responden kelompok eksperimen yang diajar dengan model pembelajaran problem based learning dan kelompok kontrol yang diajar dengan pembelajaran konvensional, keduannya dengan motivasi belajar yang berbeda masing-masing sebanyak 30 siswa. Skor empiris tertinggi 24 dan terendah 15. Dari perhitungan statistik diperoleh nilai ratarata 73,71 hal ini menunjukkan rata-rata siswa memperoleh nilai pemahaman konsep relatif cukup baik, median 72 , modus 72 , standar deviasi 9,277, dan varians 86,062 .

Pengukuan data kemampuan pemahaman konsep matematika dari 30 siswa yang berasal dari kelompok eksperimen yaitu siswa yang diberi model pembelajaran problem based learning menghasilkan nilai kemampuan pemahaman konsep matematika terendah 68 dan nilai tertinggi 96, rata-rata nilai yang dicapai adalah 81,47, simpangan baku 7,610, median 82,00, dan modus 88. Pengukuran data pemahaman konsep matematika dari 30 siswa yang berasal dari kelompok kontrol yaitu siswa yang diberi pembelajaran dengan model pembelajaran konvensional menghasilkan nilai kemampuan pemahaman konsep matematika terendah 60 dan nilai tertinggi 76 . Selanjutnya rata-rata nilai yang dicapai adalah 68,67 , simpangan baku 5,155, median 68,00, dan modus 72 .

Pengukuran data kemampuan pemahaman konsep matematika dari 30 siswa yang berasal dari kelompok siswa yang memiliki motivasi belajar tinggi, menghasilkan nilai kemampuan pemahaman konsep matematika terendah 64 dan nilai tertinggi 96. Selanjutnya rata-rata nilai yang dicapai adalah 78,93, simpangan baku 9,273, median 78, dan modus 88. Pengukuran data kemampuan pemahaman konsep matematika dari 30 siswa yang berasal dari kelompok siswa yang memiliki motivasi belajar rendah, menghasilkan nilai kemampuan pemahaman konsep 
matematika terendah 60 dan nilai tertinggi 84 . Selanjutnya rata-rata nilai yang dicapai adalah 71,20, simpangan baku 7,232, median 72, dan modus 68 .

Pengukuran data pemahaman konsep matematika dari 15 siswa yang berasal dari kelompok eksperimen yaitu siswa yang diberi pembelajaran dengan model pembelajaran problem based learning dan memiliki motivasi belajar tinggi menghasilkan nilai kemempuan pemahaman konsep matematika terendah 80 dan nilai tertinggi 96 . Selanjutnya rata-rata nilai yang dicapai adalah. 86,93, simpangan baku 4,652, median 88, dan modus 88. Pengukuran data pemahaman konsep matematika dari 15 siswa yang berasal dari kelompok eksperimen yaitu siswa yang diberi pembelajaran dengan model pembelajaran problem based learning dan memiliki motivasi belajar rendah menghasilkan nilai kemempuan pemahaman konsep matematika terendah 68 dan nilai tertinggi 84 . Selanjutnya rata-rata nilai yang dicapai adalah 76, simpangan baku 5,855, median 76, dan modus 68.

Pengukuran data pemahaman konsep matematika dari 15 siswa yang berasal dari kelompok kontrol yaitu siswa yang diberi pembelajaran dengan model pembelajaran konvensional dan memiliki motivasi belajar tinggi menghasilkan nilai kemempuan pemahaman konsep matematika terendah 64 dan nilai tertinggi 76. Selanjutnya rata-rata nilai yang dicapai adalah 70,93, simpangan baku 4,399, median 72, dan modus 72. Pengukuran data pemahaman konsep matematika dari 15 siswa yang berasal dari kelompok kontrol yaitu siswa yang diberi pembelajaran dengan model pembelajaran konvensional dan memiliki motivasi belajar rendah menghasilkan nilai kemampuan pemahaman konsep matematika terendah 60 dan nilai tertinggi 76 . Selanjutnya rata-rata nilai yang dicapai adalah 66,4 , simpangan baku 4,968, median 64 dan modus 64.

Berikut ini disajikan tabel hasil normalitas untuk model pmbelajaran, motivasi belajar dan hasil pemahaman konsep matematika . Uji normalitas data yang dilakukan adalah dengan menggunakan teknik uji kolmogorov-smirnov pada taraf signifikansi $\alpha=$ 0,05 dengan bantuan program SPSS 20 for windows seperto pada Tabel 3 berikut.

Tabel 3. Uji Normalitas

\begin{tabular}{|c|c|c|c|c|c|c|c|c|c|c|}
\hline \multicolumn{11}{|c|}{ One-Sample Kolmogorov-Smirnov Test } \\
\hline & & $\begin{array}{c}\text { Hasil } \\
\text { Pemahaman } \\
\text { Konsep } \\
\text { Matematika }\end{array}$ & $\begin{array}{c}\text { Hasil } \\
\text { Pemahaman } \\
\text { Konsep } \\
\text { Matematika } \\
\text { Dengan } \\
\text { Model } \\
\text { Pembelajaran } \\
\text { PBL } \\
\end{array}$ & $\begin{array}{c}\text { Hasil } \\
\text { Pemahaman } \\
\text { Konsep } \\
\text { Matematika } \\
\text { Dengan } \\
\text { Model } \\
\text { Pembelajaran } \\
\text { Konvensional }\end{array}$ & $\begin{array}{l}\text { Hasil } \\
\text { Pemahaman } \\
\text { Konsep } \\
\text { Matematika } \\
\text { Dengan } \\
\text { Motivasi } \\
\text { Tinggi }\end{array}$ & $\begin{array}{c}\text { Hasil } \\
\text { Pemahaman } \\
\text { Konsep } \\
\text { Matematika } \\
\text { Dengan } \\
\text { Motivasi } \\
\text { Rendah }\end{array}$ & $\begin{array}{c}\text { Hasil } \\
\text { Pemahaman } \\
\text { Konsep } \\
\text { Matematika } \\
\text { Dengan } \\
\text { Model } \\
\text { Pembelajaran } \\
\text { PBL dan } \\
\text { Motivasi } \\
\text { Tinggi } \\
\end{array}$ & \begin{tabular}{|c} 
Hasil \\
Pemahaman \\
Konsep \\
Matematika \\
Dengan \\
Model \\
Pembelajaran \\
PBL dan \\
Motivasi \\
Rendah \\
\end{tabular} & $\begin{array}{c}\text { Hasil } \\
\text { Pemahaman } \\
\text { Konsep } \\
\text { Matematika } \\
\text { Dengan } \\
\text { Model } \\
\text { Pembelajaran } \\
\text { Konvensional } \\
\text { dan Motivasi } \\
\text { Tinggi } \\
\end{array}$ & $\begin{array}{c}\text { Hasil } \\
\text { Pemahaman } \\
\text { Konsep } \\
\text { Matematika } \\
\text { Dengan } \\
\text { Model } \\
\text { Pembelajaran } \\
\text { Konvensional } \\
\text { dan Motivasi } \\
\text { Rendah }\end{array}$ \\
\hline $\mathrm{N}$ & & 60 & 30 & 30 & 30 & 30 & 15 & 15 & 15 & 15 \\
\hline \multirow{2}{*}{ Normal Parameters ${ }^{\mathrm{a}, \mathrm{b}}$} & Mean & 75.07 & 81.47 & 68.67 & 78.93 & 71.20 & 86.93 & 76.00 & 70.93 & 66.40 \\
\hline & Std. Deviation & 9.120 & 7.610 & 5.155 & 9.273 & 7.232 & 4.652 & 5.855 & 4.399 & 4.968 \\
\hline \multirow[t]{3}{*}{ Most Extreme Differences } & Absolute & .148 & .138 & .208 & .169 & .138 & .257 & .153 & .262 & .219 \\
\hline & Positive & .148 & .095 & .184 & .139 & .138 & .209 & .153 & .142 & .219 \\
\hline & Negative & -.089 & -.138 & -.208 & -.169 & -.088 & -.257 & -.153 & -.262 & -.137 \\
\hline Kolmogorov-Smirnov Z & & 1.149 & .756 & 1.138 & .927 & .754 & .997 & .592 & 1.017 & .847 \\
\hline Asymp. Sig. (2-tailed) & & .143 & .617 & .150 & .357 & .621 & .274 & .875 & .253 & .469 \\
\hline
\end{tabular}


Dari hasil analisis diperoleh nilai Sig. (2-tailed) $=0,143$. Karena nilai Sig. (2tailed) $>\alpha=0,05$, maka $\mathrm{H}_{0}$ diterima, yaitu data sampel berasal dari populasi yang berdistribusi normal. Dengan demikian dapat disimpulkan bahwa sampel penelitian ini berasal dari populasi yang berdistribusi normal. Kesimpulan ini memberikan implikasi bahwa analisis statistika selanjutnya dapat digunakan dalam penelitian ini. Ringkasan hasil perhitungan uji homogenitas antar kelompok dapat seperti pada Tabel 4 berikut.

Tabel 4. Ui Homogenitas

\begin{tabular}{cccc}
\hline $\mathrm{F}$ & $\mathrm{df1}$ & $\mathrm{df1}$ & Sig. \\
\hline .715 & 3 & 56 & .547 \\
\hline
\end{tabular}

Hasil uji homogenitas varians diperoleh nilai Sig. $=0,547$. Karena Sig. $>\alpha=0,05$, maka Ho diterima. Dengan kata lain, data dari keempat kelompok sampel penelitian berasal dari populasi yang homogen atau memiliki varians yang homogen. Berikut disajikan ringkasan hasil ANOVA dengan bantuan program SPSS 20 for windows seperti pada Tabel 5 berikut.

Tabel 5. Uji Anova

\begin{tabular}{llllll}
\hline \multicolumn{1}{c}{ Source } & \multicolumn{1}{c}{$\begin{array}{c}\text { Type III Sum of } \\
\text { Squares }\end{array}$} & df & \multicolumn{1}{c}{$\begin{array}{c}\text { Mean } \\
\text { Square }\end{array}$} & \multicolumn{1}{c}{ F } & Sig. \\
\hline Corrected Model & $3508.267 a$ & 3 & 1169.422 & 46.795 & .000 \\
Intercept & 338100.26 & 1 & 338100.267 & 13529.165 & .000 \\
A & 2457.60 & 1 & 2457.600 & 98.341 & .000 \\
B & 897.06 & 1 & 897.067 & 35.896 & .000 \\
A B $_{\text {Error }}^{153.60}$ & 1 & 153.600 & 6.146 & .016 \\
Total & 1399.467 & 56 & 24.990 & & \\
Corrected Total & 343008.000 & 60 & & & \\
\hline
\end{tabular}

Dari Tabel 5 akan diuji tiga hipotesis sekaligus, yaitu hipotesis ini untuk menguji ada atau tidaknya pengaruh model pembelajaran terhadap pemahaman konsep matematika siswa. Dari pengujian didapat nilai sig. $=0,000$ sig $<0,05$ dan $\mathrm{F}_{\text {hitung }}=$ 98,341. Dengan demikian dapat disimpulkan terdapat pengaruh yang signifikan model pembelajaran terhadap pemahaman konsep matematika.

Hipotesis ini untuk menguji ada atau tidaknya motivasi belajar terhadap kemampuan pemahaman matematika. Dari pengujian didapat sig untuk minat belajar adalah 0,000 $<0,05$ dan $F_{\text {hitung }}=35,896$. Dengan demikian dapat disimpulkan terdapat pengaruh motivasi belajar terhadap pemahaman konsep matematika.

Hipotesis ini untuk menguji ada atau tidaknya interaksi bersama antara model pembelajaran dan motivasi belajar terhadap pemahaman konsep matematika. Dari pengujian didapat sig untuk model pembelajaran problem based learning dan minat belajar adalah 0,016 0,05 dan $F_{\text {hitung }}=6,146$. Dengan demikian dapat disimpulkan terdapat pengaruh interaktif model pembelajaran dan motivasi belajar terhadap pemahaman konsep matematika. 
Penelitian ini untuk mengetahui pengaruh interaksi dari penggunaan model pembelajaran dan motivasi belajar terhadap pemahaman konsep matematika siswa. Hasil penelitian menunjukkan bahwa terdapat perbedaan pemahaman konsep matematika dalam pembelajaran ditinjau dari model pembelajaran dan motivasi belajar.

Secara definitif, Wirasto (1987: 52) memberikan ciri-ciri siswa yang sudah mampu memahami konsep adalah sebagai berikut : 1) Mengetahui ciri-ciri suatu konsep; 2) Mengenal contoh dan bukan contoh dari monsep tersebut; 3) Mengenal sejumlah sifat-sifat dan esensinya; 4) Dapat menghubungkan antar konsep; 5) Dapat mengenal hubungan antar konsep; 6) Dapat mengenal kembali konsep itu dalam berbagai situasi; dan 7) Dapat menggunakan konsep untuk menyelesaikan masalah matematika. Untuk memahami konsep dalam matematika diperlukan ketrampilan guru dalam membuat langkah-langkah pembelajaran dimulai dari konsep yang sederhana sampai ke dalam konsep yang kompleks.

Salah satu kebaikan dari model pembelajaran problem based learning adalah bahwa peserta didik belajar mengajukan pertanyaan, mencoba merumuskan pertanyaan, dan mencoba menemukan jawaban terhadap pertanyaannya sendiri dengan melakukan observasi atau pengamatan. Dengan cara seperti itu peserta didik menjadi kritis dan aktif belajar (Prayekti, 2006: 188).

Lain halnya dengan pembelajaran konvensional. Menurut Sukandi (2003) mendeskripsikan bahwa pendekatan konvensional ditandai dengan guru mengajar lebih banyak mengajarkan tentang konsep-konsep bukan kompetensi, tujuannya adalah siswa mengetahui sesuatu bukan mampu untuk melakukan sesuatu, dan pada saat proses pembelajaran siswa lebih banyak mendengarkan. Jadi di sini terlihat bahwa pendekatan konvensional yang dimaksud adalah proses pembelajaran yang lebih banyak didominasi gurunya sebagai "pen-transfer" ilmu, sementara siswa lebih pasif karena hanya sebagai "penerima ilmu". Motivasi belajar adalah suatu usaha meningkatkan atau mempertahankan setinggi mungkin kecakapan yang dimiliki untuk mencapai hasil dengan membandingkan beberapa ukuran keunggulan, yaitu keunggulan yang pernah dicapai sendiri sebelumnya atau keunggulan yang dicapai orang lain. Seseorang yang telah memiliki motivasi berprestasi tidak akan pernah merasa puas dengan prestasi belajar yang sudah diraihnya. Pemahaman konsep matematika siswa yang memiliki motivasi belajar lebih tinggi lebih baik dibandingkan dengan kemampuan pemahaman konsep matematika siswa yang memiliki motivasi belajar rendah.

Mengacu pada hasil penelitian dan didukung oleh analisis statistik untuk penelitian tentang pemahaman konsep matematika, diperoleh kesimpulan bahwa data berasal dari populasi berdistribusi normal dan berasal dari vaians yang sama (homogen). Dengan demikian data yang ada telah memenuhi uji persyaratan analisis data. Berdasarkan hal tersebut maka penelitian ini dapat dilanjutkan menuju pengujian hipotesis. Dari pengujian hipotesis tersebut dapat dianalisis sebagai berikut:

Dari pengujian hipotesis diperoleh bahwa nilai signifikan (Sig) adalah 0,000, dan $F_{\text {hitung }}=98,341$, sedangkan $F_{\text {tabel }}=4,02$. Karena nilai Sig $<0,05$ dan $F_{\text {hitung }}>F_{\text {tabel }}$ maka $\mathrm{H}_{0}$ ditolak dan $\mathrm{H}_{1}$ diterima, yang berarti terdapat pengaruh yang signifikan antara 
variabel bebas A (model pembelajaran) terhadap variabel terikat Y (pemahaman konsep matematika). Secara operasional, pemahaman konsep matematika diukur melalui tes obyektif pilihan ganda dan dengan tes tersebut seorang siswa dituntut untuk mampu menjawab soal secara tertulis sesuai dengan kemampuan yang dimilikinya.

Berdasarkan uraian teoritis tersebut dapat diasumsikan bahwa pemahaman konsep matematika seorang siswa sangat dipengaruhi oleh penggunaan model pembelajaran, dan dalam penelitian ini penggunaan model pembelajaran problem based learning lebih dominan dari pada model pembelajaran konvensional. Hal ini ditunjukkan oleh deskripsi data penelitian bahwa pada kelompok pertama (eksperimen), yaitu siswa yang diajrkan dengan model pembelajaran problem based learning dari 30 responden diperoleh rata-rata nilai tes sebesar 81,47, simpangan baku 7,610, sedangkan pada kelompok kedua (kontrol), yaitu siswa yang diajarkan dengan pembelajaran konvensional dari 30 responden diperoleh rata-rata nilai tes sebesar 68,67, dan simpangan baku 5,155.

Berdasarkan informasi kuantitatif dan teori tersebut di atas, maka peneliti berkesimpulan bahwa model pembelajaran berpengruh terhadap pemahaman konsep matematika dan dapat disimpulkan pula terdapat perbedaan pengaruh yang signifikan penggunaan model pembelajaran problem based learning dan pembelajaran konvensional terhadap pemahaman konsep matematika.

Dari pengujian hipotesis diperoleh bahwa nilai signifikan (Sig) adalah 0,000 dan $F_{\text {hitung }}=35,896$, sedangkan $F_{\text {tabel }}=4,02$. Karena nilai Sig $<0,05$ dan $F_{\text {hitung }}>F_{\text {tabel }}$ maka $\mathrm{H}_{0}$ ditolak dan $\mathrm{H}_{1}$ diterima, yang berarti terdapat pengaruh yang signifikan antara variabel bebas B (motivasi belajar) terhadap variabel terikay Y (pemahaman konsep matematika). Secara operasional, pemahaman konsep matematika diukur melalui tes obyektif pilihan ganda dan dengan tes tersebut seorang siswa dituntut untuk mampu menjawab soal secara tertulis sesuai dengan kemampuan yang dimilikinya.

Berdasarkan uraian teoritis tersebut dapat diasumsikan bahwa pemahaman konsep matematika seorang siswa sangat dipengaruhi oleh motivasi belajar, dan dalam penelitian ini kemampuan pemahaman konsep matematika siswa yang memiliki motivasi belajar tingga lebih baik dibandingan kemampuan pemahaman konsep matematika yang memiliki motivasi belajar rendah. Hal ini ditunjukkan oleh deskripsi data penelitian bahwa pada kelompok siswa yang memiliki motivasi belajar tinggi dari 30 responden diperoleh rata-rata nilai tes sebesar 78,93 dan simpangan baku 9,273, sedangkan pada kelompok siswa yang memiliki motivasi belajar rendah dari 30 responden diperoleh rata-rata nilai tes sebesar 71,29 dan simpangan baku 7,232. Dengan demikian dapat disimpulkan bahwa motivasi belajar berpengruh terhadap pemahaman konsep matematik.

Pembuktian tersebut sesuai dengan kajian teori bahwa motivasi sebagai daya pendorong yang mengakibatkan seseorang anggota organisasi mau dan rela untuk menggerakkan kemampuan dalam bentuk keahlian atau keterampilan tenaga dan waktunya untuk menggunakan berbagai kegiatan yang menjadi tanggungjawabnya dan menunaikan kewajibannya dalam rangka pencapaian tujuan dari berbagai sasaran organisasi yang telah ditentukan sebelumnya. Demikian juga dijelaskan oleh Daft (2000: 91) bahwa motivasi mengacu pada dorongan, baik dari dalam atau dari 
luar diri seseorang yang memunculkan antusiasme dan kegigihan untuk melakukan tindakan tertentu. Hal ini juga senada seperti yang disampaikan Robbins (2002: 55) bahwa motivasi adalah keinginan untuk melakukan sesuatu dan menentukan kemampuan bertindak untuk memuaskan kebutuhan individu.

Dari pengujian hipotesis diperoleh bahwa nilai signifikan ( $\mathrm{Sig}$ ) adalah 0,016 dan $F_{\text {hitung }}=6,146$, sedangkan $F_{\text {tabel }}=4,02$. Karena nilai Sig $<0,05$ dan $F_{\text {hitung }}>F_{\text {tabel }}$ maka $\mathrm{H}_{0}$ ditolak dan $\mathrm{H}_{1}$ diterima, yang berarti terdapat pengaruh yang signifikan antara variabel bebas A (model pembelajaran) dan variabel bebas B (motivasi belaar) terhadap variabel terikat Y (pemahaman konsep matematika).

Berdasarkan uraian teoritis tersebut dapat diasumsikan bahwa pemahaman konsep matematika seorang siswa sangat dipengaruhi oleh interaksi model pembelajaran dan motivasi belajar, dalam penelitian ini kemampuan pemahaman konsep matematika siswa yang memiliki motivasi belajar tinggi lebih baik dibandingkan kemampuan pemahaman konsep matematika yang memiliki motivasi belajar rendah baik yang diajar dengan menggunakan model pembelajaran problem based learning maupun yang diajar dengan menggunakan pembelajaran konvensional. Hal ini ditunjukkan oleh deskripsi data penelitian bahwa pada kelompok pertama yaitu siswa yang diajar dengan model pembelajaran PBL untuk siswa yang memilki motivasi belajar tinggi dari 15 responden diperoleh rata-rata nilai tes sebesar 86,93 dan simpangan baku 4,652, sedangkan siswa yang memiliki motivasi belajar rendah dari 15 responden diperoleh rata-rata nilai tes sebesar 76,00 dan simpangan baku 5,855. Demikian juga pada kelompok kedua yaitu siswa yang diajar dengan model pembelajaran konvensional, untuk siswa yang memilki motivasi belajar tinggi dari 15 responden diperoleh rata-rata nilai tes sebesar 70,93 dan simpangan baku 4,399, sedangkan siswa yang memiliki motivasi belajar rendah dari 15 responden diperoleh rata-rata nilai tes sebesar 66,40 dan simpangan baku 4,968. Dengan demikian dapat disimpulkan bahwa interaksi model pembelajaran dan motivasi belajar berpengruh terhadap pemahaman konsep matematika.

\section{KESIMPULAN}

Berdasarkan data yang diperoleh dapat ditarik kesimpulan sebagai berikut:

1. Terdapat pengaruh yang signifikan model pembelajaran terhadap pemahaman konsep matematika siswa SMA Negeri di Kabupaten Pandeglang.

2. Terdapat pengaruh yang signifikan motivasi belajar terhadap pemahaman konsep matematika siswa SMA Negeri di Kabupaten Pandeglang.

3. Terdapat pengaruh interaktif yang signifikan model pembelajaran dan motivasi belajar terhadap pemahaman konsep matematika siswa SMA Negeri di Kabupaten Pandeglang.

\section{DAFTAR PUSTAKA}

Daft, R. L. (2000). Manajemen. (terjemahan Emil Salin dan Iman Karmawan). Jakarta: Erlangga. 
Sodri

Prayekti. (2003). Pembelajaran kooperatif tipe PBL di Sekolah Dasar. Jurnal Pendidikan, 4(2), 1-12.

Robbins, S. P. (2002). Prinsip-prinsip Perilaku Organisasi. (terjemahan Halida dan Dewi Sartika). Jakarta: Erlangga.

Sugiyono. (2004). Metode Penelitian Bisnis. Bandung: Alfabeta.

Sugiyono. (2006). Metode Penelitian Pendidikan. Bandung: Alfabeta.

Sukandi, U. (2003). Pembeljaran Konvesioal. Surabaya: Duta Graha Pustaka.

Wirasto. (1987). Beberapa Penyebab Kemerosotan Pendidikan Matematika di Negara Kita. Makalah disampaikan pada seminar nasional pendidikan matematika di IKIP Sanata Dharma, Yogyakarta. 